\title{
ПРЕДИКТОРЫ СЕРДЕЧНО-СОСУДИСТОЙ СМЕРТИ У ЛИЦ С ВПЕРВЫЕ ВЫЯВЛЕННЫМ САХАРНЫМ ДИАБЕТОМ 2 ТИПА И С ИСТОРИЕЙ САХАРНОГО ДИАБЕТА ПО ДАННЫМ 15-ЛЕТНЕГО КОГОРТНОГО НАБЛЮДЕНИЯ
}

\author{
Рымар О.Д., Щербакова Л.В., Щетинина А.О., Малютина С.К., Мустафина С.В. \\ НИИТПМ - филиал ИЦиГ СО РАН, Новосибирск
}

ЦЕЛЬ: выявить предикторы смерти от болезней системы кровообращения за 15-летний период наблюдения у лиц 45-69 лет с историей сахарного диабета 2 типа (СД2) и с впервые выявленным диабетом.

МАТЕРИАЛЫ И МЕТОДЫ: работа выполнена в рамках проекта HAPIEЕ: «Детерминанты сердечно-сосудистых (СС) заболеваний в Восточной Европе». Обследована популяционная выборка 9360 жителей 45-69 лет г. Новосибирска. СД2 был выявлен у 982 человек. Исключены из анализа лица, имевшие в анамнезе нефатальный инфаркт миокарда и/или мозговой инсульт, лица, у которых за наблюдаемый период причиной смерти явились не СС-заболевания, и лица, о которых не получено информации за период наблюдения. В анализ включены данные базового обследования 681 человека с СД2. Диагноз СД2 был установлен до скрининга (осведомленные) у 36,7\% ( $n=250)$, впервые - при скрининговом обследовании (неосведомленные) - 63,3\% (n=431). Период наблюдения длился с 2003(05) гг. по 2018 г. Фатальные случаи в изучаемой когорте были идентифицированы путем комбинации нескольких источников информации: «Медицинские свидетельства о смерти», повторных скринингов в 2006-2008 гг. и 2015-2017 гг. и двух почтовых опросов. Причины СС-смерти были установлены в соответствии с кодами МКБ 10-го пересмотра. Оценена связь «традиционных», а также социальных и поведенческих факторов риска с СС-смертью.

РЕЗУЛЬТАТЫ: среди осведомленных о СД2 пациентов у 43,4\% мужчин и 31\% женщин произошли фатальные СС-события. Разницы в частоте фатальных исходов у осведомленных/неосведомленных мужчин не получено - 43,4\%/35,6\%, p=0,228. Чаще СС-смерть регистрировалась у осведомленных о СД2 жен щин - 31,0\%/20,6\%, p=0,018. Осведомленных о СД2 мужчин умерли от СС-заболеваний больше, чем женщин - 43,4\%/31,0\%, $p=0,059$.

У мужчин с историей СД2 риск СС-смерти за 15-летний период наблюдения повышается в 1,25 (доверительный интервал (ДИ) 1,083-1,438) раза при повышении систолического артериального давления (САД) на 10 мм рт.ст., в 6,27 раза (ДИ 1,819-21,604) у одиноких мужчин; у женщин — на $11 \%$ с увеличением возраста на 1 год (HR=1,11; ДИ 1,038-1,190), в 12,2 (ДИ 4,01-36,93) раза у курящих в настоящее время, в 3,39 (ДИ 1,43-8,07) раза у неработающих, в 2,42 (ДИ 1,207-4,864) раза при уровне глюкозе плазмы натощак $\geq 7,5$ vs $<75$ ммоль/л, в 1,17 (ДИ 1,03-1,34) раза - при повышении САД на 10 мм рт.ст.

У мужчин с впервые установленным СД2 риск СС фатальных событий увеличивается на 9\% при повышении возраста на 1 год - (HR=1,09; ДИ 1,045-1,126), в 2,68 (1,643-4,375) раза при частоте сердечных сокращений (ЧСС) $\geq 75$ vs $<75$ в минуту, в 1,27 (ДИ 1,030-1,231) раза при повышении САД на 10 мм рт.ст., в 1,80 (ДИ 1,118-2,906) раза у курящих в настоящее время; у женщин - на 17\% при повышении возраста на 1 год (HR=1,17; ДИ 1,095-1,244).

ВЫВоды: для лиц среднего и пожилого возраста, осведомленных о наличии у них СД2, выявлены следующие значимые предикторы СС-смерти: повышение глюкозы плазмы натощак, САД, семейный статус одинокого, для мужчин - низкая физическая активность; для женщин - возраст, курение в настоящее время, статус экономически не активной; среди лиц с впервые установленным СД2 - возраст, повышение САД, для мужчин - повышение ЧСС (более 75 в минуту), курение в настоящее время. Полученные данные об особенностях факторов риска СС-смерти у мужчин и женщин с историей СД2 и впервые выявленным СД могут послужить основой адресного проведения профилактических программ для лиц среднего и пожилого возраста. 